

\section{Daftar Isi (Table of Content) Journal of Government
Civil Society}

\begin{tabular}{|c|c|}
\hline \multirow{3}{*}{$1-34$} & $\begin{array}{l}\text { Akuntabilitas Politik dalam Anggaran (Studi Kasus: Dana Gerakan Dusun } \\
\text { Membangun (GDM) di Kabupaten Bungo) }\end{array}$ \\
\hline & Fajar Trilaksana Moedarlis \\
\hline & (Magister Ilmu Pemerintahan, Universitas Muhammadiyah Yogyakarta, Indonesia) \\
\hline \multirow[b]{3}{*}{$35-46$} & $\begin{array}{l}\text { Civil Servants Performance Analysis of Education, Youth and Sports } \\
\text { Department in Bantul District } 2017\end{array}$ \\
\hline & Surya Jaya Abadi ${ }^{1}$, Muhammad Eko Atmojo ${ }^{2}$, Helen Dian Fridayani ${ }^{3}$ \\
\hline & $\begin{array}{l}\left({ }^{1} \text { Government Affairs and Administration, Universitas Muhammadiyah Yogyakarta, }\right. \\
\text { Indonesia) } \\
\text { ('2Government Affairs and Administration, Universitas Muhammadiyah Yogyakarta, } \\
\text { Indonesia) } \\
\text { ('3overnment Affairs and Administration, Universitas Muhammadiyah Yogyakarta, } \\
\text { Indonesia) }\end{array}$ \\
\hline \multirow{3}{*}{$47-61$} & $\begin{array}{l}\text { Efektivitas Pengawasan Badan Pengawas Obat dan Makanan (BPOM) } \\
\text { terhadap Peredaran Makanan Impor oleh Pedagang UMKM di Kota } \\
\text { Pekanbaru }\end{array}$ \\
\hline & Ferry Angriawan1, Dyah Mutiarin² \\
\hline & $\begin{array}{l}\text { ('Magister Ilmu Pemerintahan, Universitas Muhammadiyah Yogyakarta, Indonesia) } \\
\left({ }^{2} \text { Magister Ilmu Pemerintahan, Universitas Muhammadiyah Yogyakarta, Indonesia) }\right.\end{array}$ \\
\hline \multirow{3}{*}{$63-78$} & $\begin{array}{l}\text { Institusionalisasi Partai Politik dalam Pilkada } 2017 \text { (Studi Kasus: Partai } \\
\text { Golkar Provinsi Kepulauan Bangka Belitung) }\end{array}$ \\
\hline & Agam Primadi ${ }^{1}$, Titin Purwaningsih ${ }^{2}$ \\
\hline & $\begin{array}{l}\left({ }^{1} \text { Magister Ilmu Pemerintahan, Universitas Muhammadiyah Yogyakarta, Indonesia) }\right. \\
\left({ }^{2} \text { Magister Ilmu Pemerintahan, Universitas Muhammadiyah Yogyakarta, Indonesia) }\right.\end{array}$ \\
\hline \multirow[b]{3}{*}{$79-91$} & $\begin{array}{l}\text { Public Value in Clean Water Management at the Local Water Supply Utility } \\
\text { (PDAM) Tirta Kerta Raharja (TKR) }\end{array}$ \\
\hline & Arsid $^{1}$, Ida Widianingsih'², Heru Nurasa ${ }^{3}$, Entang Adhy Muhtar ${ }^{4}$ \\
\hline & $\begin{array}{l}\text { ('Mahasiswa Program Pascasarjana Administrasi Publik, FISIP Universitas Padjadjaran, } \\
\text { Indonesia) } \\
\text { ('Pusat Studi Desentralisasi dan Pembangunan Partisipatif, FISIP Universitas } \\
\text { Padjadjaran, Indonesia) } \\
\text { ('Departemen Administrasi Publik, FISIP Universitas Padjadjaran, Indonesia) } \\
\left({ }^{4} \text { Departemen Administrasi Publik, FISIP Universitas Padjadjaran, Indonesia) }\right.\end{array}$ \\
\hline
\end{tabular}




\title{
Civil Servants Performance Analysis of Education, Youth and Sports Department in Bantul District 2017
}

\author{
Surya Jaya Abadi ${ }^{1}$, Muhammad Eko Atmojo ${ }^{2}$, Helen Dian Fridayani ${ }^{3}$ \\ ${ }^{1}$ Government Affairs and Administration, Universitas Muhammadiyah Yogyakarta, Indonesia \\ Email: suryajayaa11@gmail.com \\ ${ }^{2}$ Government Affairs and Administration, Universitas Muhammadiyah Yogyakarta, Indonesia \\ Email: atmojoeko91@gmail.com \\ ${ }^{3}$ Government Affairs and Administration, Universitas Muhammadiyah Yogyakarta, Indonesia \\ Email: helen.2016@pasca.umy.ac.id
}

\begin{abstract}
Bureaucratic reform is an effort to reform and change fundamentally in a system of governance that involves institutional aspects (organization), management (business process) and human resources apparatus to realize good governance. The lack of civil servants within the Bantul Regency Government, such as teachers, health workers and technical personnel, are caused by the presence of retired employees and the enactment of the civil servants candidate (CPNS) moratorium policy which causes the workload (ABK) figures of an organization and employees to be heavier than before which can affect public service quality. The method used in this study is descriptive qualitative. The results showed that the performance of civil servants in the Education, Youth and Sports department was very good, besides that the arrangement of work plans was also in accordance with the standards of the organization. However, there are some obstacles, especially in the timeliness of completing assignments, and the ideas or initiatives of civil servants in delivering ideas are still lacking. Meanwhile, the factors that influence civil servants performance in carrying out their tasks are lack of human resources, the presence of seniority and the lack of awareness of ASN about the importance of implementing education and training.
\end{abstract}

Keywords: Bureaucratic reform, state civil apparatus, employee performance

\begin{abstract}
ABSTRAK
Reformasi birokrasi adalah upaya untuk mengubah secara fundamental suatu sistem pemerintahan yang melibatkan aspek kelembagaan (organisasi), manajemen (proses bisnis) dan aparatur sumberdaya manusia untuk mewujudkan tata pemerintahan yang baik. Kurangnya jumlah pegawai negeri yang dialami oleh Pemerintah Daerah Kabupaten Bantul, seperti guru, tenaga kesehatan, dan tenaga teknis, terutama disebabkan karena masa pensiun dan diberlakukannya kebijakan moratorium calon pegawai negeri sipil (CPNS) sehingga angka beban kerja (ABK) organisasi dan karyawan menjadi lebih berat dari sebelumnya yang selanjutnya dapat memengaruhi kualitas layanan publik. Penelitian ini menggunakan metode deskriptif kualitatif. Hasil penelitian menunjukkan bahwa kinerja pegawai negeri sipil di Dinas Pendidikan, Pemuda dan Olahraga sangat baik. Selain itu, pengaturan rencana kerja juga sesuai dengan standar organisasi. Namun, ada beberapa kendala, terutama dalam ketepatan waktu menyelesaikan tugas dan gagasan atau inisiatif pegawai negeri dalam menyampaikan gagasan yang masih kurang. Sementara itu, faktor-faktor yang memengaruhi kinerja pegawai negeri dalam melaksanakan tugas mereka adalah kurangnya sumberdaya manusia, iklim senioritas, dan kurangnya kesadaran ASN tentang pentingnya melaksanakan pendidikan dan pelatihan.
\end{abstract}

Kata Kunci: Reformasi birokrasi, Aparatur Sipil Negara, kinerja pegawai

Citation: Abadi, Surya Jaya, Muhammad Eko Atmojo dan Helen Dian Fridayani. 2019. "Civil Servants Performance Analysis of Education, Youth and Sports Department in Bantul District 2017". Journal of Government and Civil Society, Vol. 3, No. 1, 35-46. 


\section{INTRODUCTION}

Bureaucratic reform is one of the fundamental reforms and changes in the system of governance that concerns on institutional aspects (organization), management (business process), and human resources of the apparatus. Bureaucratic reform is carried out to realize good governance. Bureaucratic reform is a strategic step to build state apparatus to be more efficient and effective in carrying out the general tasks of government and national development, therefore the goals and targets set can be achieved effectively and efficiently (www.menpan.go.id).

The State Civil Apparatus (ASN) is a profession for Civil Servantsand Government Employees with Employment Agreements (PPPK) as contained in Law No. 5 of 2014 concerning State Civil Apparatus. The State Civil Apparatus which is located as an element of the state apparatus has the function as the executor of public policy and public servants. Meanwhile, the role of State Civil Apparatus is very important, such as a planner, executor, and supervisor of the implementation of general tasks of government and national development through the implementation of professional public policies and services, free from political intervention, and clean from the practices of corruption, collusion and nepotism, an efficient and accountable public service will be created. This was also stated by Atmojo (2016) who said that in order to realize good and clean government, the state civil apparatus needed professionalism in carrying out their duties as public servants.

In the framework of bureaucratic reform, it is necessary to conduct organizational structuring and structuring of civil servants (rightsizing) to optimize the performance of human resources and efficiency of the existing employee budget. Therefore on August 24, 2011 the stipulation of the civil servants candidate (CPNS)moratorim policy in a joint regulation of the Minister of State for Administrative Reform and Bureaucratic Reform, Minister of Home Affairs, and Minister of Finance Number 02/SPB/M.PAN-RB/8/2011, Number 800-632 In 2011, Number 141/PMK.01/2011 Concerning Temporary Delays in Acceptance of CPNS. The aim of the policy is to overcome the ineffective and inefficient growth of civil servants by organizing the organization and structuring of the ASN as well as reducing the budget for employee in the regions and national scope.

Bantul Regency Government has submitted proposal to the MENPAN-RB bureaucratic reform team for the new CPNS formation in functional positions such as teacher staff, health workers (http://old.solopos.com). In addition to requiring teachers and health workers, the Government also requires the required technical staff, but the number of technical employee needed is not as much as teachers and health workers (http:// old.solopos.com). Of the three laborers the most needed teachers, this is due to the impact of the CPNS moratorium policy and the large number of elementary school ASN teachers appointed through Presidential Instruction in period I (1976), period II (1977) and period III (1978) who will retire from 2017 to 2019 (http://jogja.tribunnews.com). 
In 2016, the number of ASNs in Bantul Regency which will and/or have entered retirement period is 441 (four hundred forty one) people. The number of ASNs entering retirement period 1 July to 1 December 2016 were 223 consisting of teachers, functional health positions and general functional positions (Dahlan, 2016).The lack of civil servants within the Bantul Regency Government, especially teachers, health workers and technical servants caused by several factors including the existence of retired employees and the existence of a CPNS moratorium policy, therefore the Bantul Regency Government cannot recruit civil servants. With the lack of civil servants, the workload (ABK) of an organization and employees will be heavier than before and can also affect the quality of public servants. From the explanations, it is known that the number of civil servantsare the most needed. Therefore this study will focus on how the civil servants performance of the Education, Youth and Sports department in Bantul Regency in 2017.

\section{THEORETICAL FRAMEWORK}

\section{Human Resource Management}

According to Mangkunegara (in Permansari, 2013) human resources (HR) in companies need to be managed professionally to realize a balance between the needs of employees with the demands and capabilities of the company's organization, this balance is the main key for the company to develop productively and naturally. So, an employee or employee is an important resource that is a mandatory company or organization. It is also in accordance with what was stated by Rivai (in Rozalinda, 2016) in the management of HR employee is the main wealth (assets) of the company that must be maintained properly so that the factor that becomes a concern in HR management is the human.

Human resource management (HR) according to Mangkunegara (in Iskarim, 2017) is a planning, organizing, coordinating, implementing, and overseeing the procurement, development, remuneration, integration, maintenance, and separation of labor in order to achieve organizational goals. According to Batteman and Snell HR management is a process and an effort to recruit, develop, motivate, and evaluate the overall HR needed by the company in achieving its objectives (Rozalinda, 2016).Rivai and Sagala also added, while the final goal to be achieved in HRM is basically an increase in efficiency, increased effectiveness, increased productivity, low levels of employee transfers, low absenteeism, high employee job satisfaction, high service quality, low complaints from customers and increased company business (Yusuf, 2015). To achieve its objectives there are several activities in HRM. Meanwhile, the indicators are: HR Planning, Recruitment, Selection, Training and Development, Job Performance Assessment, Compensation, Safety Maintenance of Workers, Employee Relations. 


\section{Employee Performance}

Nawawi termed performance as a work, namely a result of the implementation of a work both physical and non-physical (Patiran, 2010). According to Istiningsih performance is the work of employees both in terms of quality and quantity based on predetermined work standards (Sriwidodo \& Haryanto, 2010). Thus, according to Mangkunegara, defining employee performance (work performance) is as a result of work in quality and quantity achieved by an employee in carrying out his duties in accordance with the responsibilities given to him (Kusuma, 2013).Dessler argues that employee performance is a work achievement, which is a comparison between work results that can be seen clearly from the work standards set by the organization (Fauza \& Wismantoro, 2014). Sherman and Gomes said that "Job performance is the number of successful role achievement". That is, work performance / performance is the number or measure of success for something achieved (Prihantoro, 2012).

According to Timple (in Kusuma, 2013), performance factors consist of internal factors and external factors:

1. Internal factors, which are factors that are related to a person's characteristics. For example, a person's performance is either caused by having a high ability, while someone has a poor performance due to having a low ability and that person has no effort to improve his abilities.

2. External Factors, which factors that influence a person's performance from the environment, such as behavior, attitudes, and actions of coworkers, subordinates or leaders, work facilities and organizational climate.

\section{RESEARCH METHODOLOGY}

This study uses descriptive qualitative methods. Qualitative research methods are usually referred to as naturalistic research methods, because the research is carried out in natural settings, also called qualitative methods because the data collected and the analysis are more qualitative (Sugiyono, 2014). This research will be conducted the Bantul Regency Youth and Sports Education Office. Data collection techniques in this study used non-participant observation, interviews, and documentation. While data analysts use the method of Miles and Huberman (2007) Tjepjep Rohendi Rohidi's translation in Nurliana (2013) said there are 3 kinds of interactive data analyst models that can be used, namely; (a) data reduction; (b) data presentation; (c) draw conclusions/verifications. 


\section{RESULTS AND DISCUSSION}

\section{The State Civil Apparatus Performance}

In order to realize good public services, it must be supported by competent and professional apparatus resources. Given the apparatus resources are the most important organs in the wheels of government. To realize this, it must be supported by the existence of bureaucratic reform in the field of staffing. Zulchaidir (2011) states that one of the efforts made by the government in increasing the capacity of the apparatus is to carry out "bureaucratic reform" in the field of staffing which is believed to lead to a condition of the government bureaucracy that is expected by the public.With the realization of competent and professional apparatus resources, it will greatly affect the performance of the state civil apparatus in each agency or bureaucracy. Therefore there are several indicators that can be done to see the performance of the state civil apparatus in the department of education, youth and sports of Bantul Regency, including the following:

First, quality of work is a result that can be measured by the effectiveness and efficiency of a work carried out by human resources (HR) in terms of achieving organizational goals well and efficiently. Based on the results of ASN works in the Department of Education, youth and sports, Bantul Regency is already good, with the existence of rewards and high awareness of the responsibility of individual ASN assignments to obtain optimal work results targeted by the organization. This is supported by Government Agency Performance Accountability Report 2017 data which shows the main performance indicators of the Education, Youth, and Sports Department of Bantul Regency.

Table 1. Key Performance Indicators 2017

\begin{tabular}{clcc}
\hline \multirow{2}{*}{ No. } & \multicolumn{1}{c}{ Key Performance Indicators } & \multicolumn{2}{c}{ 2017 } \\
\cline { 3 - 4 } & & Target & Realization \\
\hline 1. & Drop Rate of Elementary School/MI & 0.02 & 0.01 \\
2. & Drop Rate of Middle School / MTs & 0.02 & 0.02 \\
3. & Graduation Percentage of Elementary school/MI & 100 & 100 \\
4. & Graduation Percentage of Junior High School /MTs & 100 & 100 \\
5. & APK SD/MI & 96.15 & 97.73 \\
6. & APK SMP/MTs & 95.15 & 99.76 \\
7. & APM SD/MI & 84.2 & 88.25 \\
8. & APM SMP/MTs & 67.7 & 77.01 \\
9. & Continuing Numbers of elementary school/MI & 100 & 106.62 \\
10. & Continuing Numbers of junior high school/MTs & 100 & 105.96 \\
11. & Average School Length & 8.84 & 9.4 \\
12. & APK PAUD & 98.75 & 108.68 \\
13. & Provincial Level Sports Achievement Percentage & 26 & 31.4 \\
& (POPDA / Student Sports Week) Followed & & \\
14. & Number of Pioneer Youth & 4 & 5 \\
\hline
\end{tabular}

Source: Lakip Dept. of Education, Youth, and Sports of Bantul Regency in 2017 
Based on the table data above shows that the achievement of the main performance indicators of the Bantul Regency in 2017 can almost be realized with 100\% even more except for the elementary schooldropout rate indicator which is only realized 0.01 of the 0.02 target. Meanwhile, the highest realization was in the junior high school indicator of 77.01 from the target of 67.7 and the PAUDof 108.68 from the target of 98.75. Based on the performance measurement of the achievement of the main performance indicators of the Education, Youth and Sports department in 2017, it can be concluded that at 14 the target indicators are very high with an average achievement of $110.69 \%$.

In addition, there is also a match between the results of the civil servants work and the goals of the organization and the benefits of the work of the civil servants. Meanwhile, the purpose of the Department of Education, Youth, and Sports of Bantul Regency is to realize of quality education in noble character, intelligence, excellence, independence and character, improving the quality of civil servantsmore effective, efficient, transparent, and high accountability in realizing educational equity. In the target or expectation of the achievement of the resulting performance is the improvement of the quality of attitudes and mental learners, increasing early childhood education, increasing the quality of basic education and increasing the quality and quantity of education, youth, and sports department civil servants. While the benefits of the work of ASN are very helpful for the organization, especially in matters such as the implementation of tasks and problems solving faced by the existence of good cooperation between ASNs.

Secondly, the accuracy of the work plan arrangement (Renja) of the Education, Youth, and Sports department is already good, this is because there are already those who are handling the problem of scheduling program implementation activities in each of their respective fields. The implementation of activities in the work program in the Department of Education, Youth, and Sports of Bantul Regency itself can be seen from the results of evaluations carried out in the third or fourth quarter where if the budget absorption of an activity reaches 50-60 percent, it can be said that the activity has been carried out implemented, the budget was allocated to activities that were not yet possible and could be implemented so that the budget could still be absorbed.

The timeliness of ASNs in completing its work can be appropriate if there are no technical and administrative problems such as revisions, especially physical work due to delays in proposing to units that charge, there is an auction. In the case of Education, Youth, and Sports department already have the service standards such as in terms of managing diplomas and others that in theory only require 30 minutes as long as the conditions in terms of management have been completed. In work discipline with the existence of the reward it is very influential for work discipline and ASN work performance. From the explanations, it can be said that the arrangement of the work plan (Renja) by the Department of Education, Youth, and Sports of Bantul Regency is 
good, this can be seen by the civil servants that handling the problem of scheduling program implementation activities in each of their respective fields. The suitability of the work plan with the results of performance is already in conformity where we can see also in the 2017 Government Performance Report of Department of Education, Youth, and Sports, Bantul Regency. Meanwhile, the timeliness of ASN in completing its tasks still has problems, usually technical and administrative problems such as revisions, delays in proposing to units with the auction. In terms of the discipline of work ASN is good especially with the existence of rewards that can affect discipline in work and work performance of the ASN.

Third, giving ideas in dealing with problems that exist in the Department of Education, Youth, and Sports of Bantul Regency uses directives from direct leaders in terms of solving the problems. While the ASN initiative in carrying out this task is relatively relative because each ASN has different initiatives depending on the motivation of each ASN's performance. The way in the aspect of initiative giving ideas in solving problems faced is still lacking, this can be seen where direct direction is given from the leadership in terms of resolving the problems faced

Fourth, the ASN Authority has been regulated in the Governor Regulation, therefore each ASN already knows what to do and also becomes its responsibility. In addition, the autonomy has also been described by each field in Department of Education, Youth, and Sports, Bantul Regency. Each ASN has also shown that in carrying out the authority and additional tasks each ASN has done it responsibly. In the ability of ASN to manage the resources or potential that exists in the organization itself it is already good, this is supported by the effectiveness of budget accountability and resource efficiency.

Fifth, communication within the organization is an activity that is always present because communication is a tool used by employees, both formally and informally, to discuss, exchange the ideas, make reports to superiors, provide direction to subordinates and so on. Where communication is used in the service environment using two-way communication. Officials of ASN services also always maintain communication with other organizations ASN well and cooperation between ASN in organizations is also well established as in the case of implementation of authority or problems that exist in their respective fields. From a number of previous explanations, it can be said that the communication between ASNs at the service is good by using two-way communication, both vertical two-way communication such as communication between leaders and ASN and vice versa, horizontal two-way communication such as communication between ASNs and diagonal two-way communication such as communication between the Heads of Fields. It is said to be good because with two-way communication the information received is clearer and more accurate so that it can minimize the occurrence of misunderstandings in carrying out tasks and also be able to build a democratic climate in 
the work environment because it allows each party to express their responses and opinions. Likewise, external communication between ASNs and cooperation between ASNs can be said to be good.

\section{Factors Affecting the Performance of the State Civil Apparatus}

There are two factors that affecting the State Civil Apparatus Performance, which are the internal and external factors.

\section{Internal Factors}

Internal factors will greatly affect the performance of civil servants, especially in the age factor. The benchmarks that can influence the performance of the state civil apparatus in the Bantul Regency in Department of Education, Youth, and Sports are age factors, educational background, and the tasks factors. First, the age factor is inversely proportional to ASN's performance, such as increasing age, the performance of ASN will decrease which can be caused by several factors such as productivity where at a young age skills, speed, strength are better than old age apart from the economy where the elderly, especially those who are already married, are economically different from young age. From the results of interviews with head of PTK (Supardi, 2018) mentioning that ASNs aged 30-40 years were 17 or $10 \%$, ASNs aged $41-50$ years were 37 or $23 \%$ and ASNs aged $51-60$ years were 111 or $67 \%$. Thus the ASN of $51-60$ years reached the highest percentage of $67 \%$ totaling 111 ASN, while the age of 30-40 years ASN was the lowest percentage of $10 \%$, amounting to 17 ASNs. From some of the explanations above, it can be seen that the age of ASN in the Department of Education, Youth, and Sports of Bantul Regency is dominated by ASNs aged between 51-60 years, namely 111 or 67\%. Age ranges from 51 to 60 years including old age even though it is still classified as productive age, where the productive age is between the ages of 15-65 years.

Second, the level of education or educational background of the ASN can affect performance where the knowledge, experience, skills and insights that can be obtained when studying in high school or college and so on are different as well as the formation of characters in each ASN. ASN education level in the Department of Education, Youth, and Sports of Bantul Regency, ASN with junior high school education is only 1 or $1 \%$, SMA / SMK is 33 or $20 \%$, D-III is 5 or $3 \%$, S1 is 80 or $48 \%$, S2 is 45 or $27 \%$ and S3 is only 1 or $1 \%$. Thus, ASN with Education level S3 and SMP each only number 1 with the lowest percentage of $1 \%$, while the ASN S1 has the highest percentage of $48 \%$ which is as much as 80 ASN. From a number of explanations above, it can be seen that ASN with S1 education level is the most dominant with a percentage of $48 \%$, it can be said that ASN in the Department of Education, Youth, and Sports of Bantul Regency is fairly good based on ASN education level. 
Third, the difficulties faced by ASN in implementing tasks are the lack of ASN where there is an imbalance between the number of human resources and the workload that must be carried out and the culture of seniority in carrying out the work. It is known that there is an influence from authority in the ASN performance, where the availability of ASN performance will become easier because ASN can know what to do in carrying out its work. Almost all of the ASNs already knew what was being handled by each and there was a match between the education, skills or abilities possessed by the authorities carried out by each ASN. Meanwhile, the difficulties faced in implementing the authorities are: First, the lack of ASN in carrying out the work. Second, there is still a culture like seniority at work. Third, in terms of carrying out tasks which most have to partner with other organizations, which is the problem of time or schedule which must match the time and schedule between each organization.

\section{External Factors}

Whereas for external factors that can affect the performance of the state civil apparatus in the Bantul Regency in Department of Education, Youth, Sports are as follows: education and training (Diklat), leadership and organizational culture. The following is an explanation of external factors which can affect the performance of the state civil apparatus in the Bantul Regency Youth and Sports Education Office. First, Education and Trainingis an effort in developing human resources especially to develop intellectual abilities and personality of a person to be more professional in carrying out their work so that organizational goals can be achieved and have relevance to employee performance. There are 3 ASNs in the Department of Education, Youth, and Sports of Bantul Regency with groups III/c and III/d as well as the types of Education and Training that are followed, namely Training IV Leadership (Pim IV). There are 12 activities of the Department of Education, Youth, and Sprots of Bantul Regency to develop ASN. The activities consisted of a number of education and training such as the prospective school principals, basic training for childhood education, education and training for kindergarten heads, Education and Training for childhood management, education and training for school supervisors and several workshops/seminars such as Workshop to increase the capacity of principals and official apparatus resources, increase teacher competencies, supervisors and school administration staff, training candidates for functional position credit rating and functional position credit rating.

The benefits of implementing the education and training for ASN are being able to improve the capabilities or skills and competencies possessed by ASN according to their respective positions or fields. The implementation of this training itself has an impact on ASN in terms of facilitating or facilitating work in accordance with their respective positions or fields. The implementation of education and training can also affect ASN's performance 
such as in terms of discipline, leadership and patterns in team building and collaboration. As for the inhibiting factors in the implementation of training, one of them is still a lack of awareness or understanding of ASN about the importance of implementing education and training.

Second, leadership is the behavior of individuals who lead the activities of a group or organization to achieve shared goals or organizational goals. In the aspect of leadership in this study will explain the model or pattern of leadership used in the organization, how the model and pattern of leadership in influencing the performance of ASN. The leadership style used by the leaders at the education, youth, and sports department uses a democratic leadership style in which it is believed that this leadership style can develop the ASN mindset where they will be free to create as long as they do not violate the rules or vision and mission of its department. In influencing ASN performance it is believed that the model factor or leadership pattern can influence the performance of ASN where a leader who is loved, respected and can inspire ASN especially in the Department of Education, Youth, Sports of Bantul Regency. Its department leadership prioritizes a democratic leadership style which will give the ASN more freedom to create additionally as long as it does not deviate from the organization's vision and mission. The model or pattern of leadership is very influential on the performance of the ASN of the Department of Education, Youth, and Sports of Bantul Regency.

Third, the organizational culture of a system of shared meaning that is believed by all employees to distinguish an organization from other organizations. This system of shared meaning is a set of characteristics that are held in high esteem by the organization. There are several organizational cultures in the Department of Education, Youth, and Sprots in Bantul, such as work discipline, a culture of cooperation in each field, and a culture of service that is fast, friendly and has a lot of levies that were just announced in the previous year. Organizational culture is considered to influence the performance of the ASN, one example of which is the discipline of ASN where there will be differences in the results of the ASN work output between ASNs that are not disciplined in work and ASN whose work discipline. The influence of organizational culture on ASN performance is quite large where the work environment is conducive and good, the performance produced by ASN will be good too because the work environment and performance of the ASN affect each other. In organizational culture there are factors of leadership where the leader can also bring cultural factors within the organization. From the several explanations above, it can be said that organizational culture can affect the performance of ASN. Meanwhile, examples of organizational culture such as work environment, discipline of ASN, and atmosphere in organizations such as cooperation between ASNs. 


\section{CONCLUSION}

ASN Performance of the Department of Education, Youth, Sports of Bantul Regency in 2017 in terms of the quality of ASN work to obtain optimal work outcomes targeted by the organization, the ability of ASN to implement the authority and to manage existing resources or potential, as well as patterns of communication between leaders and ASNs and fellow ASNs between heads of fields are good. The aspects of accuracy are fairly good, where in the arrangement of work plans and the compatibility with the objectives of the organization but there are several obstacles in the timeliness of completing tasks such as technical and administrative issues. Meanwhile, in terms of ASN initiatives in conveying ideas or ideas in solving problems faced, they are still lacking.

The factors that influence ASN performance are measured based on internal factors such as age, level of education and external factors such as education and training (Diklat), leadership and organizational culture. The number of ASN of the Department of Education, Youth, and Sports of Bantul Regency in 2017 with the most dominant age of 51-60 years is 111 or $67 \%$ and ASN based on S1 education level is the most dominant 80 or $48 \%$ and the organizational culture in the Department of Education, Youth, and Sports in Bantul Regency a culture of discipline and a culture of service that is friendly, fast and free of charges. Meanwhile, several constraints that exist in ASN in carrying out their tasks are lack of human resources and a sense of seniority and lack of awareness of ASN about the importance of implementing education and training.

\section{REFERENCES}

Atmojo, Muhammad Eko. (2016). Analisis Proses Promosi Jabatan Aparatur Sipil Negara Studi Kasus: Proses Promosi Jabatan Stuktural Eselon II di Pemerintah Daerah Daerah Istimewa Yogyakarta Tahun 2014. Aristo Jurnal, Vol 7, Juli.

Cyntara, R. (2018, Februari 14). Pemkab Bantul Usulkan Rekrut 2.643 CPNS. (B. Suryani, Editor) Retrieved April 10, 2018, from Solopos: http://old.solopos.com

Cyntara, R. (2017, Juli 15). Ribuan Guru dan Tenaga Medis Dibutuhkan, Kapan Lowongan Dibuka? (M. D. Natalia, Editor) Retrieved April 10, 2018, from Solopos: http:// old.solopos.com

Dahlan, Y. (2016, Mei 16). Tahun Ini, 441 PNS Kabupaten Bantul Telah/Akan Pensiun. Retrieved from Badan Kepegawaian Daerah Kabupaten Bantul: https:// bkd.bantulkab.go.id

Fauza, D. H., \& Wismantoro, Y. (2014). Analisis Faktot-Faktor Yang Mempengaruhi Kinerja Pegawai Negeri Sipil Pada Badan Pertahanan Nasional Kabupaten Boyolali. Media, 22(1), 72-89.

Iskarim, M. (2017). Rekrutmen pegawai menuju kinerja organisasi yang berkualitas dalam perspektif MSDM dan Islam. Manageria: Journal of Islamic Education Management, 2(2). 
Kusuma, D. M. (2013). Kinerja Pegawai Negeri Sipil (PNS) di Kantor Badan Kepegawaian Daerah Kabupaten Kutai Timur. E-Journal Administrasi Negara, 1(4), 1388-1400.

Nurliana (2013). Pengelolaan Alokasi Dana Desa (ADD) Dalam Pembangunan Fisik di Desa Sukomulyo Kecamatan Sepaku Kabupaten Penajam Paser Utara. Journal Administrasi Negara, Volume 1. No 3.

Osm. (2017, Maret 12). Bantul Krisis Guru PNS SD. (oda, Editor) Retrieved April 10, 2018, from Tribunjogja: http://jogja.tribunnews.com.

Patiran, A. (2010). Analisis faktor-faktor yang mempengaruhi kinerja Pegawai Negeri Sipil (PNS). Fokus Ekonomi, 5(2), 32-43.

Permansari, R. (2013). Pengaruh motivasi dan lingkungan kerja terhadap kinerja PT. Anugrah Raharjo Semarang. Management Analysis Journal, 2(2), 1-19.

Prihantoro, A. (2012). Peningkatan Sumber Daya Manusia Melalui Motivasi, Disiplin, Lingkungan Kerja, Dan Komitmen. Value Added\Majalah Ekonomi Dan Bisnis, 8(2), 78-98.

Reformasi Birokrasi. (n.d.). Retrieved April 10, 2018, from Kementrian Pendayagunaan Aparatur Negara Dan Reformasi Birokrasi: https://www.menpan.go.id

Rozalinda, R. (2016). Konsep manajemen sumber daya manusia: Implementasi pada industri Perbankan Syariah. Al-Masraf, 1(1), 107-124.

Sriwidodo, U., \& Haryanto, A. B. (2010). Pengaruh kompetensi, motivasi, komunikasi dan kesejahteraan terhadap kinerja pegawai Dinas Pendidikan. Jurnal Manajemen Sumberdaya Manusia, 4(1), 47-57.

Sugiyono, 2014. Metode Penelitian Kuantitatif, Kualitatif dan RED. Alfabeta, Bandung. Yusuf, B. (2015). Manajemen Sumber Daya Manusia Di Lembaga Keuangan Syariah. (M. N. Al Arif, Ed.) Jakarta: PT RajaGrafindo Persada.

Zulchaidir (2011). Proses Rekrutmen Pimpinan Birokrasi Pemerintah Daerah di Kabupaten Sleman dan Kota Parepare. Jurnal Studi Pemerintahan, Volume 2 Nomor 2 Agustus. 